\title{
PENGGUNAAN NIRMANA-KOMPOSISI TAK BERBENTUK SEBAGAI DASAR PEMBUATAN POLA SURFACE DESIGN
}

\author{
Marina Wardaya
}

Diterima Mei. 04, 2021; Disetujui Agustus. 24, 2021

\begin{abstract}
Abstrak: Mata kuliah Nirmana menjadi mata kuliah dasar wajib untuk mahasiswa yang mempelajari desain atau seni rupa. Nirmana mengajarkan elemen maupun unsur yang terdapat dalam gambar, design dan keindahan seni dalam penggolongan elemen maupun unsur supaya tercipta suatu karya seni yang bagus dan memiliki makna, oleh karena itu menciptakan sebuah nilai estetika. Seni dan estetika adalah satu kesatuan antar elemen yang memiliki keselarasan, keserasian serta seimbang. Keindahan adalah suatu konsep abstrak yang tidak bisa dinikmati dikarenakan tidak jelas namun bisa melakukan komunikasi serta membuat senang bila dipandang. Nirmana adalah suatu core yang diimplementasikan pada pembuatan tiap design serta karya seni rupa yakni beberapa aturan yang penting dan wajib digunakan. Tujuan penelitian ini yaitu: guna melihat implementasi mata kuliah nirmana ini dalam media ready to wear. Metode yang dipergunakan yakni kajian pustaka serta pendekatan analisis secara deskriptif, eksploratif.
\end{abstract}

Kata Kunci: nirmana; pola surface design; pendidikan dasar; design

Abstract: The Nirmana course is a compulsory basic course for students studying design or fine arts. Nirmana teaches elements and elements contained in images, designs and the beauty of art in classifying elements and elements in order to create a work of art that is good and has meaning, therefore creating an aesthetic value. Art and aesthetics are a unity between elements that have harmony, harmony and balance. Beauty is an abstract concept that cannot be enjoyed because it is not clear but can communicate and make it fun to look at. Nirmana is a core that is implemented in the manufacture of each design as well as works of art, namely some important rules and must be used. The purpose of this study is to see the implementation of nirmana's courses in ready-to-wear media. The method used is a literature review and a descriptive, exploratory analysis approach.

Keywords: nirmana; surface design pattern; basic education; design 


\section{Pendahuluan}

Dunia seni rupa dan desain mengalami perubahan dan berkembang sangat pesat. Banyak karya-karya baru yang bermunculan baik bidang seni rupa ataupun di bidang desain yang menjadi bagian ilmu terapan seni rupa. Dalam pendidikan seni rupa, nirmana adalah dasar dari Pendidikan seni rupa. Nirmana berhubungan dengan penyusunan elemen atau mengorganisasi elemen visual seperti titik, garis, tekstur, warna, ruang yang menjadi kesatuan harmonis. Rangkaian bentuk dwimatra atau trimatra dari hasil imaji yang memiliki suatu keindahan bisa diartikan sebagai nirmana (Yuliansyah, 2020).

Nirmana bisa diartikan sebagai sesuatu yang abstrak atau bisa juga diartikan kosong atau tidak memiliki makna. Ungkapan ini bisa diumpamakan seperti seseorang ketika menciptakan sebuah karya seni, belum memiliki sebuah makna atau belum memiliki arti hingga akhirnya karya seni itu selesai dan memiliki sebuah arti keindahan. Hal ini sama dengan seseorang atau mahasiswa yang mulai belajar seni atau desain, pada awalnya harus menguasai pelajaran nirmana sebelum mulai atau menghasilkan sebuah karya (Sanyoto, 2017).

Nirmana adalah menjadi mata kuliah dasar yang wajib diambil oleh mahasiswa yang ingin belajar seni rupa atau desain. Dalam mata kuliah nirmana diajarkan mengenai unsur atau elemen pada sebuah gambar. Nirmana juga mengorganisasi unsur atau elemen dalam sebuah desain serta estetika sehingga menjadi suatu karya seni maupun desain yang memiliki makna dan memiliki keindahan. Keindahan dalam sebuah karya seni adalah satu kesatuan antara elemen dengan keselarasan, antara keserasian dan keseimbangan. Keindahan adalah konsep abstrak yang mungkin bagi orang awam tidak bisa dinikmati karena dianggap tidak jelas tetapi bagi orang yang mengerti seni, dapat melihat dan berkomunikasi serta menyenangkan. Nirmana adalah inti atau core dalam sebuah karya seni yang dibuat dan wajib digunakan (Hendriyana, 2020).

Dalam mata kuliah nirmana, mahasiswa diajarkan untuk mengolah rasa peka agar bisa menghasilkan sebuah karya seni, sehingga menghasilkan karya desain dengan pendekatan prinsip-prinsip desain. Prinsip dasar dari desain adalah dengan memperhatikan unsur-unsur seperti harmonisasi, proporsinya, komposisi, keseimbangan dan kesatuan (Indrajaya, 2013).

Dalam nirmana dwimatra, mengajarkan tentang bagaimana nirmana terbentuk menurut sebuah aransemen visual yang memiliki nilai artistik. Nirmana dwimatra dengan menggunakan objek geometris dasar seperti kotak, bulatan atau lingkaran, segitiga, atau bentuk dasar lainnya. Kemudian urutkan dan susun bentuk-bentuk dasar tersebut hingga membentuk pola. Nirwana dua dimensi yang memiliki pola, dibuat dengan cara memutarkan objek atau rotate, dimiringkan atau skew, menduplikasi, mengubah ukuran atau transforming, membalik objek dua dimensi atau mirror, dan menggabungkan mereka semua.

\section{Prinsip-prinsip Desain}

Dalam mendesain sebuah karya yang bagus, diperlukan keharmonisan dan keindahan. Untuk mencapai itu perlu memahami pengetahuan prinsip-prinsip desain seperti kesatuan atau unity, center of interest, keseimbangan atau balance, proportion, dan irama atau rhythm (Ayu, 2013) . Menurut Arifah A Riyanto (Riyanto, 2003), dibawah ini penjelasan masing-masing dari prinsip desain busana:

\section{A. Kesatuan}

Unity adalah suatu prinsip dasar de- 
sain yang sangat penting. Bila sebuah karya desain tidak memiliki kesatuan maka desainnya akan terlihat tercerai berai dan kacau balau sehingga menjadi tidak sedap dilihat atau menjadi tidak ada keindahan. Prinsip kesatuan sebenarnya adalah prinsip hubungan, yang mana bila salah satu unsur tidak memiliki hubungan seperti warnanya, atau arahnya, maka kesatuan tidak tercapai. Dalam desain busana perlu adanya kesatuan dan keselarasan dalam garis dan bentuk sehingga busana akan terlihat menarik dan enak dilihat. Selain serasi atau selaras dalam desain busana, serasi juga diperlukan dalam hiasan yang menunjang desain busana.

\section{B. Keseimbangan (balance)}

Dalam sebuah desain agar terlihat stabil dan menunjukan ketenangan. Untuk mencapai keseimbangan perlu menggabungkan bentuk, warna, dan garis sehingga menarik perhatian yang sama antara kiri dan kanan atau fokus pada satu sisi. Keseimbangan dapat dicapai dengan dua cara, yaitu: keseimbangan simetris (formal balance), yang merupakan keseimbangan yang dapat dicapai dengan adanya kesamaan dari kiri ke kanan kanan. Jenis keseimbangan berikutnya adalah keseimbangan Asimetris (keseimbangan informal), yang dapat dicapai dengan kombinasi posisi bentuk atau garis, warna atau ketiganya, yang berbeda antara kiri dan kanan tetapi masih menghasilkan beban yang sama sehingga seimbang.

\section{Proporsi}

Proporsi adalah salah satu prinsip dasar seni rupa agar terdapat keserasian pada suatu karya seni. Oleh karena itu perlu dilakukan perbandingan dan proporsi yang tepat. Pada hakikatnya proporsi merupakan perbandingan matematis pada suatu bidang. Proporsi (proportion) pada sebuah desain busana yaitu dengan menempatkan unsur-unsur atau bagian-bagian busana menggunakan jarak, ukuran, jumlah, tingkatan, atau bidang pada suatu model busana sehingga terlihat indah. Dengan menerapkan proporsi pada desain busana akan memberikan kesan lebih tinggi atau lebih pendek, lebih besar atau kecil pada penampilan seseorang sesuai dengan apa yang dirancang desainernya.

\section{Irama}

Pada sebuah desain busana, Irama (rhythm) merupakan suatu gerakan yang teratur berirama dari suatu bagian ke bagian lainnya, sehingga yang melihat dapat merasakan indahnya. Agar sebuah busana terlihat serasi, harmonis dan indah, diperlukan irama pada suatu desain. Irama memiliki beberapa macam disebutkan sebagai berikut: Pengulangan, Sejajar, Rangkaian, Selang-seling, Gradasi, Radiasi.

\section{E. Dominasi}

Dominasi adalah suatu prinsip dasar seni rupa yang wajib ada pada sebuah karya seni atau desain. Dominasi yang asalnya yaitu dari kata Dominance dengan arti keunggulan. Dominan yang berarti unggul ini berguna sebagai unsur penarik atau di dunia desain sering menyebutnya Focal Point, Center of Interest, serta Eye Catcher. Dominasi memiliki tujuan yakni guna menarik perhatian, mengurangi rasa bosan serta guna memecah ketimpangan.

Karya nirmana selalu menarik karena di dalamnya terdapat kompleksitas dan harmoni seni. Selain itu banyaknya bentuk, penipuan mata yang kadang objek seakan-akan bergerak sendiri. Hal ini dikarenakan cara melihat objek tersebut dan sudut pandang dari objek yang dilihat. Ini lebih menuju pada unsur seni dan estetika seni rupa atau estetika desain. Dengan mengetahui konsep dasar desain dalam mata kuliah nirmana, mahasiswa memiliki acuan dalam merancang sebuah karya atau desain khususnya dalam busana ready to wear. 


\section{Pengertian Tekstil}

Tekstil yang dalam bahasa latin, yaitu textiles yang memiliki arti menenun atau tenunan. Secara umum tekstil memiliki arti memintal sebuah serat yang menjadi sebuah benda (spinning) menjadi benang lalu dianyam/ditenun (weaving) atau bisa juga dirajut (knitting) menjadi kain, setelah dilakukan penyempurnaan (finishing) digunakan untuk bahan baku produk tekstil (Burke, 2011). Salah satu inovasi yang dilakukan oleh manusia pada produk tekstil sehingga memiliki nilai estetis dan ekonomis yang lebih tinggi dan memberikan ragam hiasan. Sehingga kain tersebut memiliki corak dan motif yang berwarna dengan berbagai macam teknik. N. Sugiarto Hartanto (1979) dalam (Djafri, 2003). Tekstil juga salah satu hasil karya inovasi manusia yang memiliki fungsi sebagai alat melindungi tubuh dari udara panas dan dingin, melindungi dari ancaman cuaca, alam, dan juga sebagai bagian dari lifestyle manusia modern. Tekstil berasal dari lembaran kain yang berbentuk anyaman benang lungsin dan pakan. Tekstil bisa juga diartikan sebagai jalinan antara lungsin dan pakan atau bisa juga dikatakan sebuah anyaman yang mengikat satu sama lain melalui tenun dan rajutan (Dunnewold, 2020). Manusia menggunakan tekstil un-

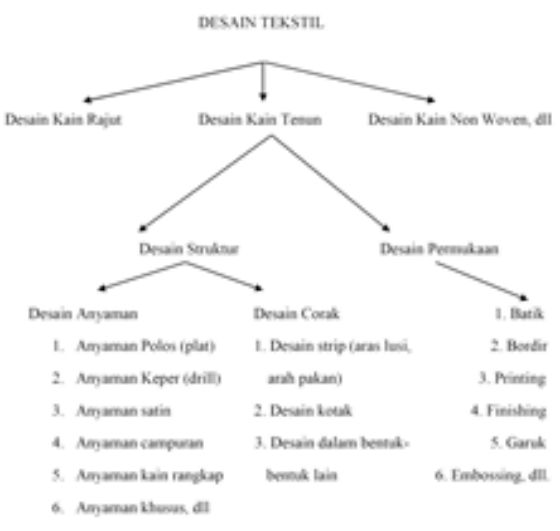

Gambar 1. Bagan Desain Tekstil (Sumber: Dasar-Dasar, BBT Bandung) tuk memenuhi kebutuhan hidup sebagai salah kebutuhan pokok yaitu sandang.

\section{Surface Design}

Shannon memaparkan bahwa surface design yaitu desain yang diaplikasikan dalam permukaan sebuah karya agar membuat indah maupun menambah permukaannya, maka bisa menambah tampilan visual serta kegunaanya. Desain itu bisa didapat dari bentuk yang ada pada alam sekitar atau bentuk yang abstrak ( $\mathrm{McNab \text {, }}$ 2016).

Desain permukaan yaitu merancang, melahirkan, serta membentuk motif yang memiliki bentuk 2D di permukaan kain. Biasanya desain ini dilakukan pada kain yang mempunyai warna putih polos dengan cara membentuk beberapa jenis motif serta warna, maka kain itu mempunyai keunikan, estetika, serta kekhasan tersendiri (Irwin, 2015).

Surface design adalah motif yang diterapkan dalam sebuah kain sesudah kain itu jadi atau selesai ditenun. Rezendes, $\mathrm{C}$ mengungkapkan bahwa surface design bisa dibuat melalui beberapa metode (Rezendes, 2013), yaitu:

1. Monotype, Collagraph, and Gellatin Prints ; Monotype adalah salah satu jenis, karya seni yang unik. Ini adalah bentuk seni grafis yang paling sederhana, hanya membutuhkan pigmen, permukaan untuk mengaplikasikannya, kertas dan beberapa bentuk press. Collagraph pada dasarnya adalah cetakan yang dibuat dari kolase. Gambar dirakit dari bahan kolase dan direkatkan ke cetakan yang bisa berupa selembar karton atau papan pemasangan. Seni grafis gelatin adalah proses planografi, yang berarti seseorang mencetak dari permukaan yang datar

2. Stamping and Relief Printing; stamping adalah pencetakan stempel grafir adalah metode di mana tinta dalam ce- 
ruk tergores atau dipotong ke permukaan pelat cetak Relief printing, dalam seni grafis, proses yang terdiri dari pemotongan atau pengetsaan permukaan cetak sedemikian rupa sehingga semua yang tersisa dari permukaan asli adalah desain yang akan dicetak.

3. Nature Printing ; metode menghasilkan cetakan objek alami (seperti daun) atau tekstil (seperti renda) dengan membuat kesan langsung ke pelat cetak logam lunak di bawah tekanan besar dan kemudian membuat kesan bertinta di atas kertas, kain atau kanvas.

4. Stencilling Techniques; Stensil, dalam seni visual, teknik untuk memproduksi desain dengan melewatkan tinta atau cat di atas lubang yang dipotong karton atau logam ke permukaan yang akan dihias,

5. Fold and Color; produk menggambar yang dirancang untuk anak-anak mengembangkan kognisi warna dan menumbuhkan kreativitas dengan menggambar.

6. Marbling Methods; metode desain permukaan berair, yang dapat menghasilkan pola yang mirip dengan marmer halus atau jenis batu lainnya. Pola adalah hasil dari warna yang diapungkan pada air biasa atau larutan kental yang dikenal sebagai ukuran, dan kemudian dengan hati-hati dipindahkan ke permukaan penyerap, seperti kertas atau kain.

7. Working with Resist ; salah satu dari berbagai metode pewarnaan kain dalam pola dengan pra-perawatan area yang dirancang untuk menahan penetrasi oleh pewarna.

8. Silk-Screen Printing ; Sablon dapat berupa operasi tangan atau proses mesin otomatis. Kain pertama-tama diletakkan di atas meja cetak, dilekatkan pada posisinya atau disematkan ke abu-abu belakang, dan kemudian desain diterapkan melalui layar yang terbuat dari kain kasa sutra atau nilon yang direntangkan di atas bingkai kayu atau logam, di mana desain untuk satu warna telah direproduksi.

9. Drawing on Fabric; menggambar di atas kain adalah cara unik untuk mengekspresikan visi desain Anda dan membuat efek grafis khusus.

10. All That Glitters ; Efek khusus dapat menambah nilai pada pekerjaan cetak apa pun.

11. Image Transfer.

12. Sewing: As Embellishment, Accent, and Texture.

Menurut penjelasan di atas, teknik surface design bisa dibuat melalui beberapa cara dengan persyaratan motif diberikan sesudah kain itu jadi. Tidak hanya itu, surface design juga bisa diaplikasikan sebagai hiasan, aksen, serta sebagai tekstur. Prosesnya dalam dunia modern misalnya bisa diaplikasikan pada kain yaitu dengan teknik printing.

\section{Digital Print}

Digital printing merupakan metode pencetakan yang modern untuk mencetak suatu gambar yang dikerjakan oleh komputer ke permukaan material oleh printer. Biasanya, proses tersebut dilakukan pada pekerjaan percetakan yang memiliki jumlah yang banyak. Dengan metode ini, beberapa macam keperluan cetak bisa terselesaikan secara akurat dan cepat. Tidak hanya dikaitkan dengan industri cetak yang memiliki jumlah besar, namun juga bisa berhubungan dengan perusahaan promosi baik indoor atau outdoor (Dameria, 2012).

Penerapan digital printing umumnya dipakai sebagai alat promosi perusahaan sampai pelaksanaan pilkada maupun pileg tingkat provinsi maupun kabupaten/ kota berupa billboard, brosur, spanduk, 
banner maupun baliho. Sekarang, teknologi digital printing berjalan secara cepat agar memenuhi beberapa macam keperluan pelanggan. Hal tersebut bisa ditunjukkan dengan munculnya mesin digital printing dengan teknologi yang modern dan canggih, dengan menambah alatnya menjadi mesin scanner, mesin yang memiliki fungsi berbagai macam mulai dari untuk copier dan print based, juga bisa untuk faksimili dan dilanjutkan menjadi e-mail, bahkan membuat pelanggan menjadi hemat dalam penggunaan kertas sebagai perbuatan yang bisa melestarikan lingkungan.

Tetapi, bisnis ini telah kian sempit wadahnya, khususnya untuk pelaku usaha yang kurang kreatif, menjadikan beberapa pengusaha harus siap melakukan persaingan dengan pengusaha yang lain. Selanjutnya, ada tuntutan bagi para pengusaha agar berjalan dengan cepat juga responsive. Sebaliknya, untuk pelaku usaha yang kreatif, bisnis ini adalah wadah yang tepat untuk memulai usaha dengan biaya rendah. Salah satunya adalah dengan membuat kain dengan desain khusus dan jumlah terbatas.

Busana ready to wear merupakan busana yang siap dipakai atau busana jadi tanpa harus mengukur badan terlebih dahulu atau memesan desain seperti saat kita memesan untuk dibuatkan baju ke penjahit (Poespo, 2018). Tujuan penelitian ini yaitu: Bagaimana menerapkan mata kuliah nirmana ini dalam media ready to wear?

\section{Metode Penelitian}

Dalam menjawab persoalan yang terdapat penelitian ini tentang penggunaan nirmana- komposisi tak berbentuk sebagai dasar pembuatan pola surface design, maka menggunakan metode kajian pustaka dan pendekatan analisis secara deskriptif, eksploratif.. Metode yang dipakai dalam penelitian ini adalah metode kualitatif, dan teknik pengumpulan data yang dipergunakan ialah dokumentasi, dan studi pustaka yang dikaitkan dengan tahap tingkatan lapangan, guna menjalankan keberhasilan suatu tindakan penelitian. Penelitian dengan pendekatan kualitatif bersifat deskriptif, yaitu mengadakan pengamatan langsung pada objek penelitian terhadap penggunaan nirmana-komposisi tak berbentuk sebagai dasar pembuatan pola surface design.

\section{Hasil dan Pembahasan}

Berdasarkan penelitian yang pernah dilakukan dan teori-teori pada bab pendahuluan, yang menyebutkan bahwa nirmana mirip dengan (ilmu) yakni terkait mengkategorikan sesuatu agar mencapai mutu artistik dalam suatu desain. Nirmana berisi beberapa hal terkait keselarasan rasa, harmoni, serta kesan dalam suatu bentuk.

Menurut Bruche Archer (Sanyoto, 2005), desain yaitu suatu bentuk kebutuhan jasmani serta rohani seseorang yang dipaparkan dengan beberapa bidang keahlian, pengalaman serta pengetahuannya yang menggambarkan perhatian terhadap adaptasi serta apresiasi pada sekitarnya, khususnya yang berkaitan dengan komposisi, bentuk, nilai, arti, juga beberapa tujuan benda buatan manusia. Sementara menurut Lou Lenzi, desain merupakan aktivitas yang memberikan arti dunia usaha ke arah strategi kompetisi (Sachari \& Suranti T., 2011).

Menurut Andri rancangan desain dianggap selesai apabila telah bisa dipandang berupa fisik. Di dunia professional, media objek itu dibagi menjadi tekstil, produk, ruang, serta grafis. Pada perbedaan media olah atau ungkap itu dibedakan disiplin desain menjadi produk, desain interior, tekstil, dan grafis, yang keseluruhannya memperlihatkan pengetahuan terhadap media olahan yang ber- 
beda. Bagian terakhir dari proses tersebut yaitu dibentuknya rancangan yang berupa fisik. Bentuk tersebut yang kemudian akan berkaitan dengan manusia. Bisa dikatakan aspek yang selanjutnya akan berkaitan dengan manusia yaitu aspek fisik yang diserap seseorang melalui indra raba atau visual (Ardiansyah, 2010).

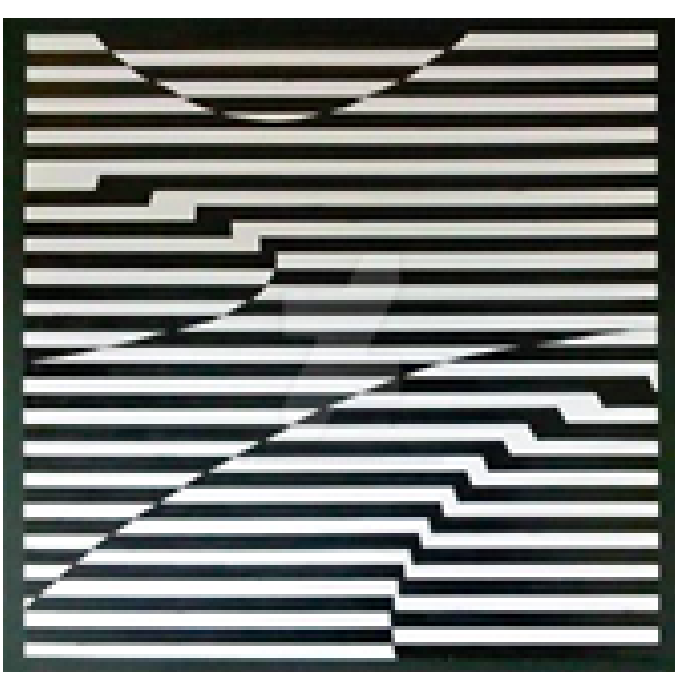

Gambar 2. Garis

(sumber : williamsetiawan.deviantart.com/)

Unsur adalah dasar utama dalam desain. Ketika seseorang hendak membuat atau merancang sebuah desain maka diperlukan acuan unsur-unsur. Menurut ebook Textile Design (A. Briggs-Goode \& K. Townsend, 2011) unsur desain tersebut yaitu sebagai berikut:

Garis adalah sebuah tanda yang dibuat dengan pena atau gambar instrument, bisa juga berupa tanda terus menerus tanpa putus sehingga menyebabkan mata mengikuti jalurnya. Dalam hal seni, garis dianggap sebagai titik yang bergerak. Ini memiliki jumlah kegunaan yang tak ada habisnya dalam penciptaan seni. Garis seperti terlihat di Gambar 2. dapat mengontrol arah pada yang memandang.

Bentuk adalah sebuah garis yang saling bertemu dari titik awal hingga akhir sehingga terciptalah sebuah bentuk (Pen- tak \& Lauer, 2015). Value adalah ketajaman atau kontras yang membuat mata tertarik untuk memperhatikan serta permainan cahaya terhadap efek gelap atau terang sehingga menghasilkan sebuah ilusi (Dunnewold, 2020).

Tekstur didefinisikan sebagai permukaan sebuah material yang bisa dirasakan oleh indera perasa atau sentuhan, sehingga manusia bisa merasakan atas permukaan sebuah objek yang mungkin merasakan halus, kasar, licin, berbulu, lembut, berpasir atau bergelombang. Seperti contoh trend kaos usap anak-anak dimana gambarnya memiliki tekstur yang bila diusap bisa berubah warna (Burke, 2011)

Warna bisa diasosiasikan sebagai waktu hari, cuaca kondisi dan suhu, dan bahkan bisa dianggap sebagai musim sepanjang tahun. Warna bisa digunakan sebagai rancangan untuk kamuflase dengan lingkungan. Semua sinar cahaya mengandung warna. Cahaya terbuat dari gelombang elektromagnetik. Gelombang ini menyebar dari sumber cahaya manapun, seperti matahari. Gelombang cahaya merambat dengan kecepatan luar biasa (186.000 mil atau 300.00o kilometer per detik). Warna yang berbeda memiliki panjang gelombang yang berbeda, yang merupakan jarak antara bagian yang sesuai dari dua gelombang. Panjang gelombang cahaya terpanjang yang dapat dilihat manusia adalah merah. Yang terpendek adalah ungu. Dalam desain warna bisa digunakan untuk segala macam rancangan busana. Contohnya untuk menyesuaikan dengan keadaan medan gurun, seragam tentara Amerika yang dikirim ke timur tengah dibuat seperti warna gurun (Faiers, 2016). Warna adalah aspek sesuatu yang disebabkan oleh perbedaan kualitas cahaya yang dipantulkan atau dipancarkan olehnya.

Menurut penjelasan di atas, teknik surface design bisa dibuat melalui beberapa cara dengan persyaratan motif diberi- 
kan sesudah kain itu jadi. Tidak hanya itu, surface design juga bisa diaplikasikan sebagai hiasan, aksen, serta sebagai tekstur. Prosesnya dalam dunia modern misalnya bisa diaplikasikan pada kain yaitu dengan teknik printing.
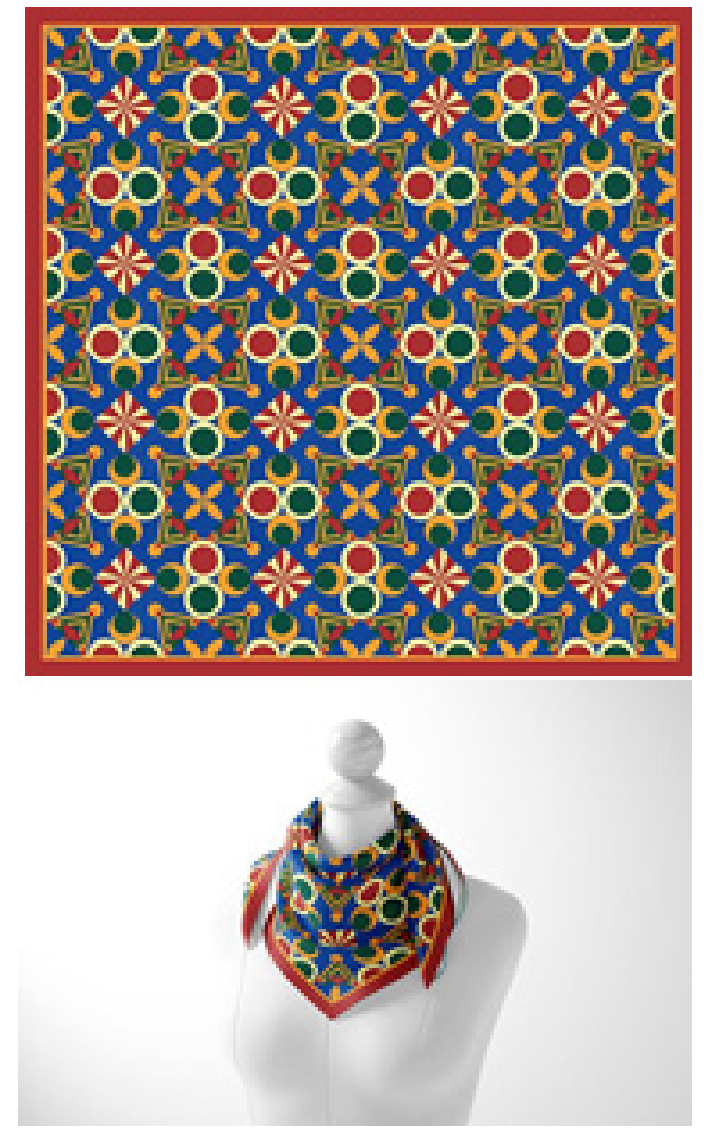

Gambar 3. Motif scarf pengaplikasian Nirmana (sumber : dokumentasi pribadi)

Pada tingkat awal perencanaan pembuatan scraf mahasiswa memahami terlebih dahulu mengenai nirmana. Mulai kesatuan, keseimbangan, bentuk, garis, warna dan mencobanya. Dalam membuat desain pola surface design mahasiswa menggunakan nirmana, dan memulai trial and error dalam memadupadankan bentuk, warna, garis. Mereka membuat beberapa pola pada kertas dan melihat hasilnya sebelum dibuat scarf.

Dalam pembuatan scraf ini mahasiswa

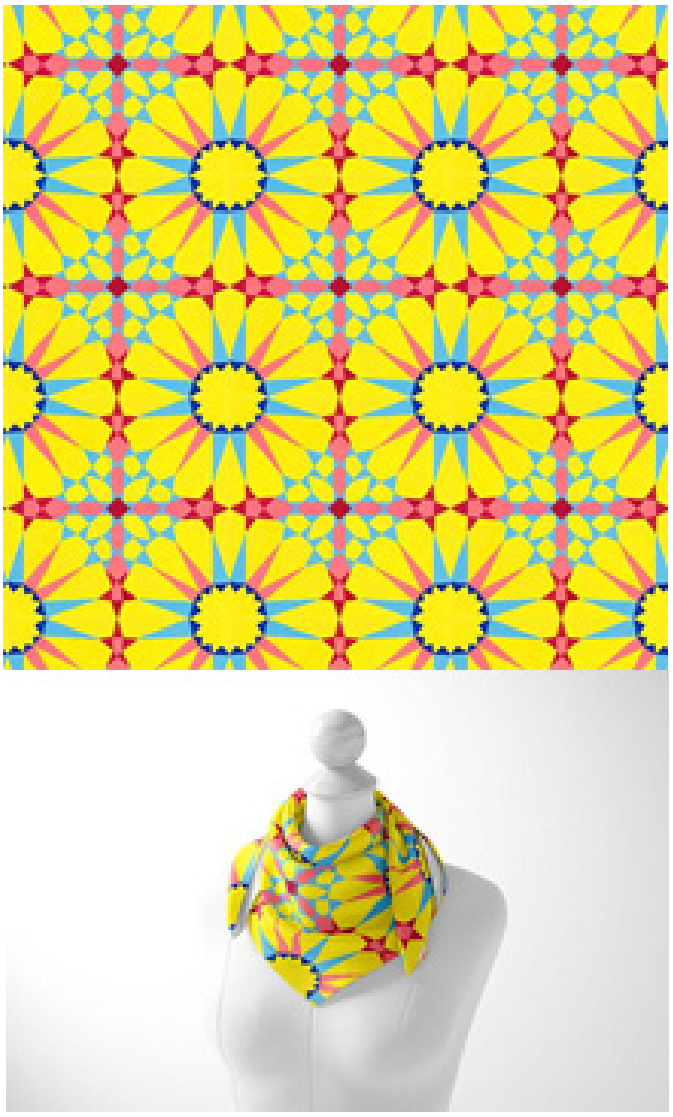

Gambar 4. Motif Scarf pengaplikasian Nirmana (sumber : dokumentasi pribadi)

menggunakan nirmana dwimatra yang dengan mulai membuat objek dasar geometris seperti kotak, segitiga, lingkaran, serta bentuk dasar lainnya yang membentuk bentuk organis. Bentuk dasar yang sudah dibuat diatur dan disusun sedemikian rupa sehingga membentuk sebuah pola yang cocok untuk scarf. Pola dan bentuk dari nirmana dwimatra umumnya dibuat dengan cara memutarkan objek atau rotate, dimiringkan atau skew, menduplikasi, mengubah ukuran atau transforming, membalik objek dua dimensi atau mirror, dan langkah kombinasi dari kesemuanya sehingga membuat sebuah pola yang cantik untuk scarf. Kreativitas berlangsung dengan proses seleksi, yang dilanjutkan dengan mengusulkan berbagai variasi dan dilanjutkan dengan pemindahan ga- 
gasan.

Setelah mencoba beberapa bentuk ataupun pola nirmana dan mahasiswa memahami serta mendapatkan arti seni yang indah. Mereka bisa mengaplikasikan nirmana dalam pembuatan scraf yang menggunakan digital printing. Seperti pada Gambar 2. dan Gambar 3. di atas motif scarf yang menggunakan bentuk dalam nirmana. Bentuk adalah sebuah garis yang saling bertemu dari titik awal hingga akhir sehingga terciptalah sebuah bentuk. Serta value dimana ketajaman atau kontras yang membuat mata tertarik untuk memperhatikan serta permainan cahaya terhadap efek gelap atau terang. Dan juga garis dimana sebuah tanda yang dibuat dengan pena atau gambar instrumen, bisa juga berupa tanda terus menerus tanpa putus sehingga menyebabkan mata mengikuti jalurnya.

Karya nirmana dwimatra, melalui kreativitas seni, berarti suatu karya yang mempunyai suatu kandungan nilai seni. Karya seni berarti suatu karya, produk apapun, atau jasa yang tercipta yang mempunyai prinsip-prinsip seni, sehingga dinyatakan sebagai karya seni yang tentunya berdaya guna baik bagi seniman maupun bagi orang lain. (Sp, 2018)

Hal ini menunjukan bahwa nirmana dwimatra bertujuan untuk dipersepsi oleh masyarakat melalui panca indera mereka, output atau hasilnya adalah pencitraan dari objek-objek yang menawarkan kebebasan imajinasi dengan mengapresiasi keindahan bentuk-bentuk yang dijadikan scarf. Tidak hanya pengetahuan tetapi juga keberanian untuk mencoba dan mengeluarkan semua kreatifitas untuk bisa menghasilkan perpaduan yang indah.

Kreativitas untuk bisa membuat pola yang dinamis sehingga menyatu menjadi kesatuan antara bentuk geometris dan juga pemilihan warna yang sesuai. Bagaimana mahasiswa berani mencoba mengeluarkan imajinasi dalam sebuah karya seni dengan menggunakan nirmana. Bagaimana membuat sebuah komposisi, memainkan warna dalam bentuk agar terlihat indah bila scarf itu digunakan.

\section{Kesimpulan}

Dalam mengintegrasikan seni terdapat tiga acara pembelajaran, yaitu mempelajari tentang atau learning about the arts, lalu dengan learning with the arts belajar dengan, dan yang terakhir adalah belajar lewat seni atau learning through the arts. Belajar dengan seni terjadi jika seni diperkenalkan kepada siswa sebagai cara untuk mempelajari materi pelajaran tertentu.

Nirmana adalah inti yang diaplikasikan pada pembuatan tiap karya desain. Dengan mempelajari mata kuliah nirmana, bisa diketahui terkait elemen yang terdapat dalam sebuah lukisan, gambar maupun karya seni. Dalam mengkategorikan suatu unsur supaya menjadi karya rupa yang bagus serta bermakna. Dengan hal tersebut, diharapkan seseorang akan mempunyai definisi, bisa menggali kemampuan, serta mengasah kepekaan terhadap semua hal yang bersangkutan dengan dunia desain.

Dengan mempelajari nirmana mahasiswa bisa menciptakan ide kreatif dalam pembuatan desain permukaan seperti yang terlihat dalam contoh pembahasan di atas. Penerapan nirmana dalam surface design pada penelitian akan menambah nilai estetika busana dan juga sebagai sesuatu yang bisa digunakan dan dikembangkan dalam desain busana. Dari pembelajaran dan penerapannya yang dilakukan mahasiswa, maka dapat disimpulkan bahwa proses awal dalam perancangan dalam pembuatan karya scarf tidak serta merta membuat mahasiswa memiliki pemahaman yang utuh. Proses awal terli- 
hat sangat lambat, dan banyak kesalahan dalam berkreasi, namun keadaan ini tidak berlangsung lama, sebab dengan melihat contoh-contoh karya nirmana dwimatra pada perkuliahan sebelumnya, atau dari karya kreator lain menjadi pemecahannya.

Jika dilihat lebih mendalam, mempelajari nirmana sama dengan mempelajari ilmu tentang bagaimana mengorganisasikan sesuatu agar memiliki nilai artistik pada karya seni atau desain. Karena nirmana mengandung tentang nilai yang harmoni, sebuah keselarasan rasa, dan kesan yang ditampilkan pada bentuk yang dapat diaplikasikan pada semua bidang seni rupa dan desain.

\section{Referensi}

Ardiansyah. (2010). Perancangan Ikat Celup Dengan Teknik Cabut Warna Untuk Bahan Pakaian.

Ayu, A. P. (2013). "Nirmana-Komposisi Tak Berbentuk" Sebagai Dasar Kesenirupaan Fakultas Seni Rupa Institut Kesenian Jakarta. Jurnal Ilmiah WIDYA, 1(2), 113-120.

Briggs-Goode, A \& Townsend, K. (2011). Textile Design: Principles, Advances, and Applications . Woodhead Publishing.

Burke, S. (2011). Fashion Designer Concept To Collection. Burke

Publishing.

Dameria, A. (2012). Designer Handbook: Dalam Produksi Cetak Dan Digital Printing. Jakarta Link \& Match Graphic.

Djafri, C. (2003). Gagasan seputar pengembangan industri dan perdagangan TPT (tekstil dan produk tekstil). Asosiasi Pertekstilan Indonesia (API) dan Cidesindo.
Dunnewold, J. (2020). Art Cloth: A Guide to Surface Design for Fabric. Independently published.

Faiers, J. (2016). Colors in Fashion (1st ed.). Bloomsbury Academic.

Hendriyana, H. (2020). Rupa Dasar Nirmana, Asas Dan Prinsip Dasar Seni Visual (1st ed., Vol. 1).

Indrajaya, F. (2013). Übermensch sebagai Radikalisasi Filsuf Alamiah (Krisis Pelampauan Diri Dalam Dunia Pendidikan Desain). Humaniora, 4(2). https://doi.org/10.21512/humaniora. v4i2.3558.

Irwin, K. (2015). Surface Design for Fabric. Fairchild Books.

McNab, S. (2016). What is Surface Design?

Pentak, S., \& Lauer, D. A. (2015). DesignBasics (9th ed.). Cengage Learning.

Poespo, G. (2018). A to Z Istilah Fashion. Gramedia.

Rezendes, C. (2013). Fabric Surface Design: Painting, Stamping, Rubbing, Stenciling, Silk Screening, Resists, Image Transfer, Marbling, Crayons \& Colored Pencils, Batik, Nature Prints, Monotype Printing. Workman Publishing Company.

Riyanto, A. A. (2003). Teori Busana (1st ed.). Yapemdo.

Sachari, A., \& Suranti T. (2011). Kamus Desain (2nd ed.). ITB Press.

Sanyoto, S. E. (2005). Dasar-dasar tatarupa \& desain (Nirmana) (1st ed.). Arti Bumi Intara.

Sanyoto, S. E. (2017). Nirmana: elemen-elemen seni dan desain (Rahmat Widada, Ed.; 2nd ed.). Jalasutra.

Yuliansyah, H. (2020). Mengungkap Karakter Kreatifitas 3 Karya Nirmana Dwimatra. Pantun, 5(1). 